SLIM A. [2019], "Economic Cycles by Joseph Schumpeter", in A. Anquetil \& T. Hoerber (eds), Economic theory and Globalization, Palgrave Macmillan, pp. 125-142. Lien.

\title{
Economic Cycles by Josef Schumpeter
}

Assen Slim

e-mail: assen.slim@essca.fr / assen.slim@inalco.fr

Summary
Introduction.
Schumpeter's Thought
From "Economic Circuit" to Fluctuation
Creative Destruction and the Three-Cycle Schema
Bibliography.




\section{Introduction}

One economist of the twentieth century whose ideas speak to us today is Joseph Alois Schumpeter (1883-1950). Looking at the number of articles and books quoting his name, it seems that researchers and analysts have recently rediscovered Schumpeter and his work (see, for example, Clemence 1988; Hagedoorn 1996; Lakomski-Laguerre 2006). According to an analysis published in the Journal of the History of Economic Thought, "annual citations to Schumpeter have continued to increase more than 50 years after his death. For social scientists, since the mid-1990s, annual citations to Capitalism, Socialism, and Democracy have even exceeded annual citations to Keynes's General Theory" (Diamond 2009, p. 538).

Throughout his life, Schumpeter always assigned a special place to the economic theory whose purpose was to deal with what he called "the economic mechanisms." This chapter explores these mechanisms Schumpeter analyzed. Firstly, a brief introduction to Schumpeter's business cycle theory will be presented. As we shall see, "innovations" tending to form "clusters" will disturb whatever equilibrium exists and are responsible for three different kinds of cycles that simultaneously unfold. The Schumpeterian vision of capitalism, seen as a dialectically evolving process (in the same tradition as Marx, Sombart, and Weber), will be discussed. Finally, Schumpeter's thought may have a vital relevance to help us explain emerging issues (such as Globalization and international specialization of countries, industry dynamics, and endogenous growth).

\section{Schumpeter's Thought}

\section{From "Economic Circuit" to Fluctuation}

Without recalling here all of Schumpeter's contributions to economic theory ${ }^{1}$, it is important to emphasize his particular conception of growth. Inspired by Wicksell's intuition ${ }^{2}$ about the importance of investment for economic growth, Schumpeter dissociates it from the analysis of monetary phenomena. This made him produce, from 1912 onwards, an original interpretation of growth, which he sometimes called "evolution" (Schumpeter 1912, p. 106). And this is where Marx comes in. Schumpeter was probably the only pro-capitalist economist influenced more by Marx than by Smith. According to Schumpeter, Marx (1867) was interested in precisely the same problem, which is to build "a vision of economic evolution as a distinct process generated by the economic system itself" (Schumpeter 1937, p. 166). So, just like Marx (1867), Schumpeter starts his analysis from an initial state of the economy where there is no growth. He calls this situation "economic circuit" (equivalent to Marx's "simple reproduction" $\left.{ }^{3}\right)$. He describes it as a situation where the different structural elements are reproduced identically (demography, wages, rent, production). This is a simplified representation of economic life and the relationships between economic agents. It is characterized by free competition, private property, and division of labor. Methods of production and consumption

\footnotetext{
${ }^{1}$ This is very well done by Richard V. Clemence (1988).

${ }^{2}$ Wicksell was a Swedish economist who built a general synthetic economic theory in which payments to a factor of production correspond to their marginal productivity.

${ }^{3}$ According to Marx, "Simple reproduction" is the process by which the capitalist will reproduce his base capital, and the worker will reproduce the conditions and necessities of his labor.
} 
practices remain stable. Supply is equal to demand so that the allocation of resources is always efficient.

Consequently, there are no changes, no doubt, no uncertainty, and no cycles or crises. The economic circuit always remains at its Walrasian general equilibrium ${ }^{4}$. Schumpeter compares it to the bloodstream. The economic agents, who act based on their past experience, introduce no fundamental break in their behavior and economic relations in place. Routine behaviors and adaptive mechanisms then lead to stability. The intrinsic model of a stationary economy causes no endogenous change. The stationary economy can only change to ensure its reproduction (from an imbalance, it manages by its own operation to return to the initial balance).

Schumpeter then questions the origins of growth (equivalent to "expanded (or enlarged) reproduction" in Marx). Being, however, radically different from the Marxist analysis of surplus value (Marx 1867, pp. 237-256), Schumpeter argues that the transition from the "economic circuit" to "evolution" finds its origin in "innovations." But how can a disturbance appear in the economic circuit?

In his book Theory of Economic Development (1912), Schumpeter develops the concepts of "entrepreneurs" and "innovations," leading to the emergence of a "business cycle." According to the author, the circular flows in the circuit are interrupted by the presence of "entrepreneurs." Quoting Cantillon (1755) and Say (1803), Schumpeter defines an entrepreneur as a person who combines land, labor, and capital to create goods and services. But for Schumpeter, an entrepreneur can identify market opportunities and exploit them by organizing resources effectively to accomplish an outcome that changes existing interactions in the economic circuit. Guided by the pursuit of profit, entrepreneurs are seen as "innovators," which means they are key players in changing business standards and finding new productive combinations. Someone willing to accept a high level of personal, professional, or financial risk to pursue an opportunity. "If I had listened to my consumers, I would have given them a quicker horse!" 5 . This sentence of Henry Ford is often cited as an example to illustrate the typical Schumpeterian entrepreneur. Here is the origin of economic change, inherent to the economic process itself and disturbing whatever equilibrium exists. Schumpeter insists that "external factors" from the circuit such as wars, inflation, and political changes that lead to an economic change are not relevant to his analysis. They are not coming from inside the economy. Wars are responsible for the cessation of activity as men fight at the front lines. Inflation creates waves in the economy just like "revolutions, natural catastrophes, institutional changes, but also changes in commercial policy, in banking and currency legislation and habits of payment, variations of crops as far as due to weather conditions or diseases, changes in gold production as far as due to chance discoveries, and so on" (Schumpeter 1935, p. 3). These "external factors" should be disregarded, Schumpeter says, if we want to get a truthful image and understand the economic changes.

Growth factors are, for Schumpeter, mainly summarized in the concept of innovation. An innovation (as distinguished from "invention" or "experimentation"), Schumpeter says, is more than just minor changes put together: "Innovations are changes in production functions which cannot be decomposed into infinitesimal steps. Add as many mail-coaches as you please, you will never get a railroad by doing so" (Schumpeter 1935, p. 4). Schumpeter distinguishes the invention, which is the discovery of new scientific and technical knowledge, from innovation which is its application's in a practical sense helping companies to improve their productivity: "the inventor produces ideas, the entrepreneur gets

\footnotetext{
${ }^{4}$ Walrasian General Equilibrium shows how and why a free market tends toward equilibrium in the long run. Walras proved that any individual market was necessarily in equilibrium if all other markets were also in equilibrium.

${ }^{5}$ Les Echos, 20 November 2003.
} 
things done, which may but need not embody anything that is scientifically new. Moreover, an idea or scientific principle is not, by itself, of any importance for economic practice. That Greek science had probably produced all that is necessary to construct a steam engine did not help the Greeks or Romans to build a steam engine; the fact that Leibnitz suggested the idea of the Suez Canal exerted no influence whatever on economic history for two hundred years" (Schumpeter 1991, from Schumpeter's Lowell Lectures of 1941, p. 413).

Schumpeter defines five types of innovations, being all considered as "opportunities to produce" (Schumpeter 1947, p. 89). These innovations refer either to technical progress or to the widening of markets and/or sources of supply for companies: "The fundamental impulse that sets and keeps the capitalist engine in motion comes from the new consumers' goods, the new methods of production or transportation, the new markets, the new forms of industrial organization that capitalist enterprise creates" (Schumpeter 1947, p. 83).

Innovations play a central role in growth, Schumpeter says, when they occur in the critical sectors of the economy. When innovations arise in these sectors, they have a ripple effect and induce a new demand. First, there is a set of entrepreneurs who successfully introduce innovations that lead to new companies new markets. Their profits are the result of successful innovations in the market. Attracted by these new opportunities, others will follow the path. That means other companies will produce the same new products just by imitating the first innovator. Schumpeter calls this behavior "imitation." Without hope of profits, people are not encouraged to innovate. So, innovation is followed by imitation. These two behaviors explain evolution through cyclical movements.

\section{Creative Destruction and the Three-Cycle Schema}

After a major innovation (a breakthrough innovation due to technical progress or scientific progress for instance), other related innovations are brought by this discovery, called by Schumpeter "cluster of innovations" (Schumpeter 1935, p. 4). According to Schumpeter, the occurrence of clusters determines the economic cycles. He considered these clusters as the main cause of what he calls "creative destruction" ( Schumpeter, 1943b, p. 26). It refers to a "process of industrial mutation, if I may use that biological term, which incessantly revolutionizes the economic structure from within, incessantly destroying the old one, incessantly creating a new one. This process of creative destruction is essential to capitalism. It is what capitalism consists of (...)" (Schumpeter 1947, p. 83). Creative destruction is an endless process which is simultaneously producing the disappearance of sectors of economic activity in conjunction with the creation of new economic activity. Schumpeter compares it to the "perennial gale" (Schumpeter 1947, p. 84). It can affect all kinds of organizations, even the most important ones or those supposed to enjoy previously a strong and dominant position, including a monopoly in the market. Successful innovation is normally a source of temporary market power, providing new monopolistic benefits to the innovative company. According to Schumpeter, interests and profit are in essence the remuneration for innovations. 


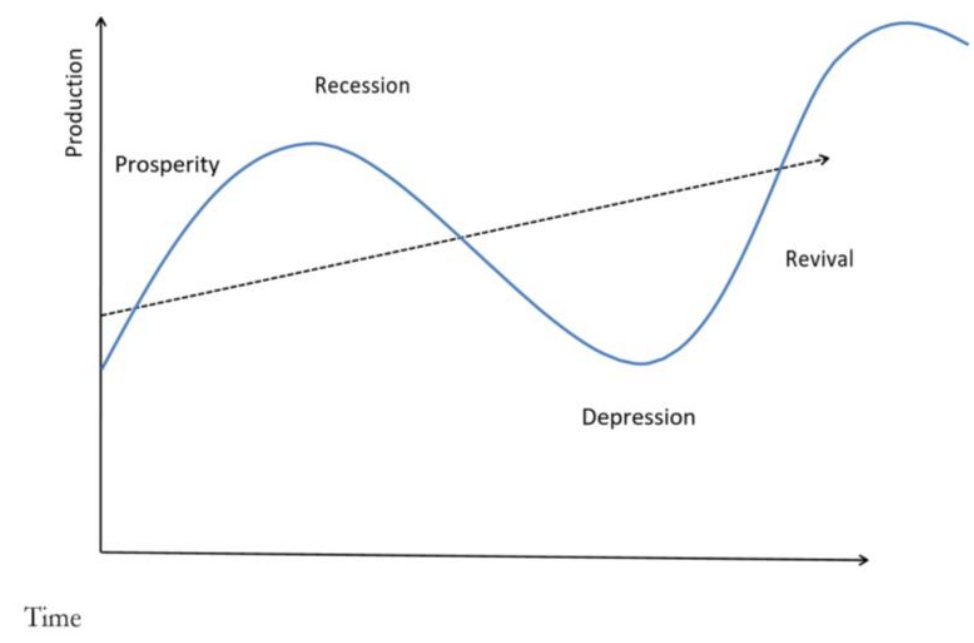

Fig. 1 The cycle (Source Inspired by Schumpeter [1935, p. 7])

As a result, clusters correspond to periods in which innovative companies see their profits increase while companies unable to follow the movement of innovations, trapped in the economic circuit and the inherent routines, see their profits eroded. In this sense, "profit is the child and the victim of evolution" (Schumpeter 1912, p. 223). With the combination of its destructive and creative effects, this process shows how powerful the dynamic changes in economic and industrial activities are. And they are also social effects to be expected from creative destruction, such as layoffs of workers with obsolete working skills and new opportunities for workers able to adapt their skills to the new requirements. This forces workers to refine their skill set.

Creative destruction leads to the emergence of a cycle, which is described by Schumpeter as a "wavelike movement" (Schumpeter 1935, p. 6), including four phases: prosperity, recession, depression, and revival (Fig. 1). "These fluctuations do not occur independently in every such time series, but always display either instantaneous or lagged association with each other" (Schumpeter 1935, p. 3).

The expansion phase is explained by the profits that increase investment and demand, driven by innovation clusters. Initially, loans will cause inflation of capital goods and consumption. Then, the additional quantity of goods generates deflation, accentuated by the repayment of loans announcing depression. The profit opportunities are few in this phase, and companies fail. This means that innovations destroy outdated companies and cause job losses. The imitation phenomenon causes saturation of markets and a decline in monopoly rents, leading to a reduction in investment followed by a decrease in economic activity. The crisis can only be overcome by other waves of innovation. This is the powerful mechanism of cyclical activity, which involves the process of creative destruction.

As innovations appear discontinuously over time, "there is no ground to believe that there should be just one wave-like movement pervading economic life" (Schumpeter 1935, p. 7). Some cycles may be short while others should take much more time to have full effect. Schumpeter describes three different cycles. The Kondratieff cycle is a long wave cycle ("between fifty-four and sixty years") due to major innovations such as the steam engine, railway, electrical engineering, etc. The Juglar cycle ("from nine to ten years") is linked to periodic disturbance of credit. And finally, the Kitchin cycle is the shorter wave cycle ("roughly forty months") due to volatility in the stock market (Schumpeter 1935, pp. $6-8)^{6}$.

\footnotetext{
${ }^{6}$ Schumpeter named the cycles in the names of the economists who brought them to light.
} 
As innovations appear discontinuously over time, "there is no ground to believe that there should be just one wave-like movement pervading economic life" (Schumpeter 1935, p. 7). Some cycles may be short, while others take much more time to full effect. Schumpeter describes three different cycles. The Kondratieff cycle is a long wave cycle ("between fifty-four and sixty years") due to significant innovations such as the steam engine, railway, electrical engineering, etc. The Juglar cycle ("from nine to ten years") is linked to periodic credit disturbance. And finally, the Kitchin cycle is the shorter wave cycle ("roughly forty months") due to volatility in the stock market (Schumpeter 1935, pp. 6-8)7.

\section{Capitalism in the Oxygen Tent}

Despite the dynamic nature of capitalism ${ }^{8}$, Schumpeter remains pessimistic (especially in his book Capitalism, Socialism and Democracy, 1947) about its future. According to Schumpeter, the capitalist process has an evolutionary character. It went through various stages over time. The first stage is called by the author "Early capitalism" (from the Greco-Roman period to the sixteenth century), and "factories were producing for markets; there were bankers; and merchants that traded internationally" (Schumpeter 1946, p. 801). The second stage was the "Mercantilist capitalism" (from the sixteenth to the eighteenth century) in the State which raised taxes against the interests of the bourgeoisie and "the bourgeoisie indeed accepted that supremacy" of the State (Schumpeter 1946, p. 802).

The third stage is called "Intact capitalism" (from the Napoleonic wars to the end of the nineteenth century). It is based on free trade, low taxes, technical progress, peace, economic growth, and social inequalities. "It was the success of the capitalist enterprise that raised the bourgeoisie to its position of temporary ascendancy" (ibid., p. 803). Finally, the "Modern phase" (from 1898 and later) in which nearly all of what Schumpeter found positive in the previous stage has disappeared or was reversed to high levels of taxes, rampant protectionism, wars, etc.

Schumpeter outlines all the events and structural changes that will lead to the collapse of capitalism. First, he describes how an important distinction must be made between preference and prognosis in making a predictive judgment and how Marx was the first to realize and approach the fundamental question. Schumpeter then analyses the reasoning behind what is necessary to make an accurate prognosis, refuting Marx's argument and presenting an alternative assessment for the exact prediction. Schumpeter then compares how his tendencies are apparent in the changes in the world and how one might make an assessment for the immediate future.

Schumpeter explains the difference between objective observation and the consequent estimation of an economic trend compared to subjective evaluations, leading to future economic developments. Schumpeter then states that the first to distinguish between a prognosis and a personal assessment was Karl Marx; however, Schumpeter shows that Marx's assertions cannot be accurate. In particular, Schumpeter contests the tendency for labor to be driven to a revolution due to the growing misery deriving from the capitalist system, as Marx suggests. Even though Marx's assumptions were wrong, that does not discount the resultant argument that capitalism will indeed fail. (Approaching the same conclusion from a different set of inevitabilities.) In contrast, it is not the proletariat, Schumpeter

\footnotetext{
${ }^{7}$ Schumpeter named the cycles in the names of the economists who brought them to light.

${ }^{8}$ Under the combined effects of endless innovations, the capitalist machine is constantly kept on the move.
} 
argues, that will overthrow capitalism due to its miseries, but the disconnection between the forces of innovation and the capitalist process itself.

Schumpeter and the concepts of innovation are closely related. In his prediction of the fall of capitalism, this is apparent. Schumpeter asserts that his prediction of the loss of leadership and strength of the entrepreneur will become the reason for the fall of capitalism.

As the growth of capitalist societies continues, the entrepreneurs are slowly replaced by an increasingly mechanized system of specialized groups of management staff designed to perform the management duties required of an entrepreneur. This is an important observation about the inevitable tendency of capitalist institutions to produce social groups hostile to the capitalist system, such as bureaucrats and administrators. This is further compounded by the growing distance of the capitalist class to the lower classes, resulting in loss of a holistic appreciation and control of the economic systems they are in charge of, as well as a loss of the motivations of upward social mobility. The result is an increasing bureaucratization of economic functions and increasing support of the labor interests, undermining the necessary innovation in a capitalist system.

Schumpeter distinguishes between the fall of capitalism and the rise of socialism. He does not predict full-fledged socialism but rather a transitional state that would neither be capitalism nor socialism. Schumpeter states that this process of gradual change, in contrast to Marx's view of a violent revolution, would happen through small and compounding changes in the life of the bourgeoisie. He argues that cumulative internally driven change is far more potent in bringing the capitalist system to collapse than an external revolution.

Applying these principles to the major upsets of the capitalist systems of his time, Schumpeter considered how the impact of the First World War accelerated conditions unfavorable to capitalist systems. This leads him to describe the immediate future in the transformation capitalist society has already undergone at the time of writing of Capitalism (1945). Analyzing the degree of control that governments held at the time, it was apparent that extensive measures of control in capitalist systems (see Chapter on Hayek in this book) were already present, controls for labor and capital markets, for pricing and for income distribution were all present. Schumpeter adds that state-driven initiatives to control factors including housing and foreign investment would be enough to transform these regulated capitalist systems into guided Capitalism without even necessitating a mass nationalization of industries. Schumpeter says that this type of Capitalism may even be called Socialism and goes on to state that survival of Capitalism in such a society becomes more minor a matter of such a society's explicit values, but more a matter of terminology: "such a system will no doubt still be called Capitalism. But it's Capitalism in the oxygen tent - kept alive by artificial devices and paralyzed in all those functions that produce the success of the past" (Schumpeter 1943b, p. 142). Finally, it would take a reversal of the existing trends towards a pseudo-capitalist society and a change in the political, societal, and economic fundamental structures to go back to "real" Capitalism.

Schumpeter presents a different explanation of the fall of capitalism compared to Marx. Yet, in analyzing the real world of his time, Schumpeter presents the fall of capitalism not as violent as the revolutionary suggestion by Marx. He argues that the growth of socialist bodies in a capitalist society leads to a diverse organization with socialist and capitalist elements. Schumpeter presents an optimistic solution to the conflict between socialism and capitalism that he gave as an unbiased prognosis of a naturally balancing evolution of human societies. 


\section{Schumpeter's Dividends}

Schumpeter currently receives great attention for his research, neglected mainly outside academic circles. His visionary views of capitalism and the concepts he has produced provide relevant tools to analyze current issues. We will focus on a few of them, i.e., a new approach of international specialization, industrial dynamics, and the case of the music industry.

\section{A New Approach of International Specialization}

Smith (1776) and Ricardo (1817) predicted that the international division of labor emerged from globalization. Each country specializes in the production of goods in which it has an advantage ("absolute" according to Smith, "comparative" according to Ricardo). The comparative advantage theory of Ricardo has greater explanatory power than Smith's theory. It shows that countries are interested in specializing, even if they have no absolute advantage. The specialization of each country is based on differences in opportunity costs. It saves labor costs, promotes productivity gains, and increases the volume produced. Later, the mainstream neoclassical current explained international specialization by differences in factor endowments. For Heckscher (1919) and Ohlin (1933), for instance, countries no longer differ by level of technology but by the factors of production (labor, capital, natural resources) with which they are endowed. As goods differ by the factors of production they require to be produced, the Hecksher-Ohlin model posits that a country will produce at lower cost the goods whose production requires relatively large amounts of the factors of production with which that country is relatively well endowed. In other words, countries will have comparative advantages in producing goods that use the abundant factor of production in the country.

Adopting a Schumpeterian view on international specialization leads to a radically new understanding of comparative advantages. One of the first authors to highlight the importance of technological innovation in explaining countries' international competitiveness was Posner (1961). The author observes that new products and processes are constantly being developed. According to him, countries that can implement at least one of the five types of innovation introduced by Schumpeter will enjoy comparative advantages over their partners. But sooner or later, the imitation process will occur, mainly because of the diffusion of technology. The determinant, therefore, lies in the temporary technological gap between countries. Advanced countries export intensive goods in new technologies while the other countries are specialized in standardized goods. Consequently, comparative advantages and export performance are directly related to the intensity of research and development efforts (expenditure on research and development, number of scientists and engineers, number of patents, etc.). Posner's analysis can therefore be seen as a revision of Ricardo's model.

These observations have been deepened and formalized by Krugman (1979). In his simple generalequilibrium model, Krugman considers two regions (the innovating Northern and non-innovating Southern hemispheres). Schumpeterian innovation takes the form of new goods produced first in the North and only after a given period in the South. This technological gap, Krugman says, gives rise to trade, "with the North exporting new products and importing old products" (Krugman 1979, p. 254). The author then shows how new industries emerge permanently in the North to maintain the income level of this area. For Krugman, the technological monopoly of the North is being continually eroded by technological transfers. It can only be supported by constant innovation. The high wages of the North reflect the temporary monopoly rent for new technologies (Krugman 1979, p. 263). 
Vernon (1966), on his side, focuses on the latest product itself and on its life cycle, which was suggested but never studied by Schumpeter. Vernon makes a link between the product's life cycle and the structure of international trade. A product, Vernon says, can experience three or four phases: emergence, growth, maturity, and decline. During the first phase, the production is intensive in new technology; then, its growth and mass production requires high capital intensity (investments). The last stages of maturity and decline characterized a standardized and labor-intensive product. At first, the product is manufactured for its domestic market (1st phase). It is then exported (2nd phase), the innovative firm and country benefiting abroad from their temporary technological monopoly. Eventually, exports will slow down and stop due to the foreign imitation process. The product can even be imported by the country which first launched it. The product life cycle thus corresponds to a cycle of international trade where the products at the beginning of their cycles will be exported by the technologically advanced countries (developed countries). In contrast, the products at the end of their cycles will be exported by the low-skilled and cheap labor countries (underdeveloped countries). The product cycle is staggered over time, for these different countries according to their respective level of development, will give rise to a dynamic view of international trade, where comparative advantages are changing from one group of countries to another, like a "wild gees flight" (to use the expression of Akamatsu 1962, p. 18).

The numerous empirical verifications of this neo-Schumpeterian approach of international specialization found a strong correlation between the export performance of the countries and the importance of their Research and Development or the number of patents. In general, the higher the level of industrialization, the greater is the tendency to export new and differentiated products.

\section{Industrial Dynamics}

A rich neo-Schumpeterian evolutionary literature has developed on the notion of "industrial dynamics." The aim is to understand how an industrial sector facing a profound technological innovation reacts (Hamdouch 2006, p. 10). Depret and Hamdouch highlight, for instance, how the techno-industrial dynamic is reshaping the different dimensions of the whole biomedical industry, namely through new patterns of behavior, new legal frameworks (laws, regulations, standards, types of contracts, the system of property rights, etc.), new scientific and technological structures (research programs, research institutions), new economic structure (financing processes, reorganization of the market), new political organization (forms of power), new social requirements (labor market, trade unions) and even new cultural models (languages, beliefs, values, habits, customs) (Depret and Hamdouch 2007, p. 90). This industrial evolution shows a particular trajectory of industrial change which combines both order and continuity factors (such as routines, learning effects, path dependence, irreversibility, lock-in) and disorder and discontinuity effects (radical uncertainty, mutations, paradigm shifts, emergence of new institutions, instabilities, deviation enhancers, selfreinforcing processes) (Paulré 2004).

The Music industry provides another excellent example of such an evolution. This industry has been confronted for a few decades to a radical innovation cluster that affects the traditional enterprises at three different levels: digitalization of content, distribution, and marketing, delivery, and exhibition. Digitalization has provided the music industry with more choice and broader dissemination and promotion. The range of formats through which music is carried has changed (cassettes, vinyl, CDs, DVDs, digital layouts, etc.). "Significantly, many costs associated with the manufacture and duplication of physical products [e.g., CDs, spindle cases, printing packaging] are removed or greatly reduced with 
the advent of digital" (Rogers and Sparviero 2011, p. 10). Thus, a life cycle of music media emerges in Vernon's sense (Fig. 2).

The distribution and marketing stage has been disrupted by the development of the Internet. Its emergence as a medium for mass communication allows the producers of content (artists, singers) to bypass the established traditional music industry in getting their creations directly to a mass audience. "Producers of music would be able to directly access their public without the machinery of a multinational corporation mediating this relationship. Costs associated with distribution and retailing would be eliminated. Rather, the rapid diffusion of Internet technologies would mean anyone could potentially enter the market" (Burnett 2011, p. 441). For the delivery and exhibition stage, the significant change lies in the method of Peer-to-Peer exchange. This allows anyone to bypass the traditional music distributors in getting the music files electronically and potentially for free.

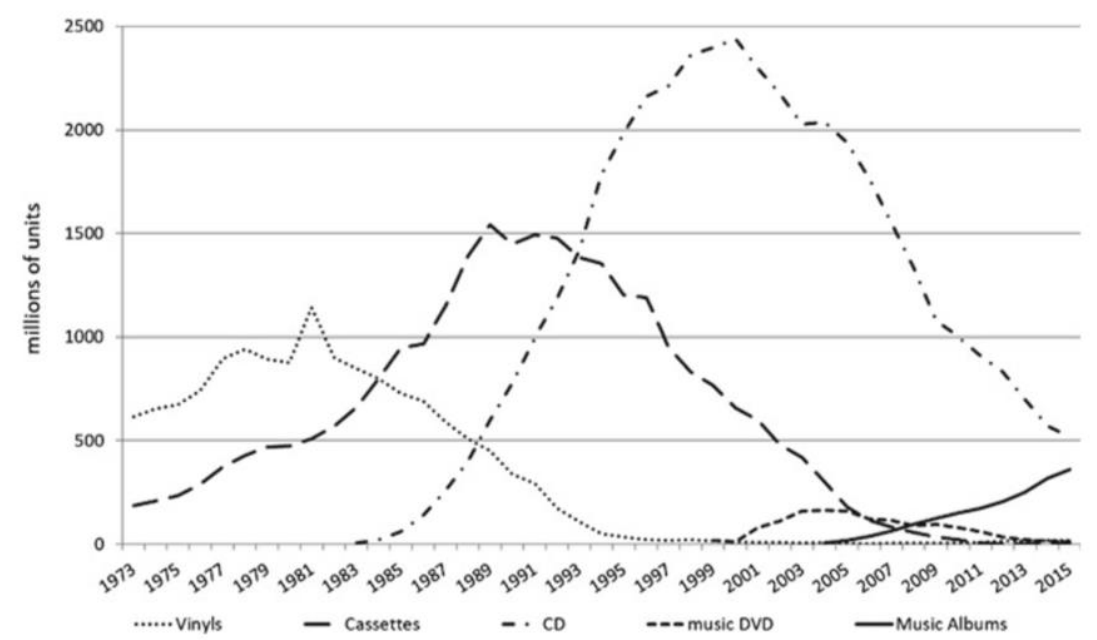

Fig. 2 Album sales by media from 1973 to 2015 (millions of units) (Description it appears on the figure that the album sales show a cycle for each media which seems to confirm the intuition of Vernon. Source Calculated from several reports of the Federation of Phonographic Industries [IFPI 2010, 2013, 2014 and 2015])

One can clearly see how the Schumpeterian creative destruction process is triggered in the music industry. Even the big music companies such as EMI Music Group, Sony Music Entertainment, Warner Music Group have to keep innovating to survive. It is a period where change is demand-driven rather than supply-pushed. The claim that free downloads of music files are 'illegal' or attempts to introduce locks, like the Digital Rights Management (DRM), will not stop the creative destruction process.

As Schumpeter predicted, it is clear that resistance to evolution is futile. The technical and legal responses of the entrenched companies in the music industry are doomed to fail. They should adapt their activities from being music manufacturers to service providers. And free exchanges of files on the Internet do not exclude profit as shown in the freemium business models or advertisement models. "Freemium" is the contraction of "free" and "premium." It is a pricing model by which a music offering is provided free of charge, but money (premium) is charged for additional features or services. "Advertisement model" means a site offers free content to customers and sells advertising to make money. New trends give a clear indication of what is expected: more music, better variety, and free exchanges. 


\section{Conclusion}

How does the capitalist system work, and how will it evolve? Which forces are driving globalization? These questions are the most difficult ones ever asked. Among all the authors who tried to answer, Schumpeter gave the best answers: Research efforts create "innovations" which are created by "entrepreneur" (who is not the same person as capitalist). Banking credit is essential to support entrepreneurs in making innovations. Finally, innovation is responsible for "creative destruction," an opportunity for evolution.

With the benefit of hindsight, we can see Schumpeter's answers still having an impact in today's world. It can explain new causes for economic change. In this sense, Schumpeter is a modern author. However, Schumpeter poses a real challenge to the economic discipline and its working hypotheses. The most difficult one is to start to explain the actual dynamics of the economy! Schumpeter invites us to rethink each concept of economic theory (such as the Ricardian comparative advantage model). It insists on the importance of governments and big companies to intensify their efforts in supporting ambitious research and development programs. It shows that innovation is the essence of globalized capitalism and that nothing lasts forever. This is the main reason why capitalism is a process of constant evolution. Is this evolution a good thing?

"The question of appraisal of social gains from entrepreneurship... is so complex and perhaps hopeless that I beg to excuse myself from entering into it," answers Schumpeter (1991, p. 34). But finally, Schumpeter was pessimistic about the future of capitalism because he believed innovation would vanish.

\section{Bibliography}

Akamatsu, K. (1962), "Historical Pattern of Economic Growth in Developing Countries," The Developing Economies, vol. 1, n¹, pp. 3-25.

Burnett, R. (2011), "Internet and Music," in M. Concalco and C. Ess (eds.), The Handbook of Internet Studies, Malden, MA: Wiley-Blackwell.

Cantillon, R. (1755), Essai sur la Nature du Commerce en Général, Paris: Institut Coppet, Edition de 2011.

Clemence, R. V. (1988), Essays: Joseph A. Schumpeter, New Brunswick (USA) and London (UK): Transaction Publisher.

Depret, M.-H., Hamdouch, A. (2007), "Changements technologiques, logiques institutionnelles et dynamiques industrielles. Esquisse d'une approche co-évolutionnaire appliquée à l'industrie pharmaceutique et aux biotechnologies", Innovations, vol. 1, n²5, pp. 85-109.

Diamond, A. M. (2009), "Schumpeter vs. Keynes: In the Long Run Not All of Us Are Dead," Journal of the History of Economic Thought, vol. 31, n4, pp. 531-541.

Hagedoorn, J. (1996), "Innovation and Entrepreneurship: Schumpeter Revisited," Industrial and Corporate Change, vol. 5, n³, January, pp. 883-896. 
Hamdouch, A. (2006), "Les institutions de la connaissance et du développement scientifique et technologique: Un cadre d'analyse à partir d'une étude comparative européenne", Caiete Sociologice / Cahiers sociologiques, $n^{\circ} 4$, pp. 7-43.

Heckscher, E. F. (1919), "The effect of foreign trade on the distribution of income", Ekonomisk Tidskriff, pp. 497-512. Translated as chapter 13 in American Economic Association, Readings in the Theory of International Trade, Philadelphia: Blakiston, 1949, pp. 272-300.

Heckscher, E., Ohlin, B. M. (1991), Trade Theory, Cambridge, MA: MIT Press. Krugman,

P. (1979), "A Model of Innovation, Technological Transfer, and the World Distribution of Income," Journal of Political Economy, vol. 87, n², April, pp. 253-266.

Lakomski-Laguerre, O. (2006), "Introduction à Schumpeter", L’Economie politique, vol. 1, n²9, pp. 8298.

Marx, K. (1867), Le Capital, Livre premier: le procès de production du capital, Quadrige: PUF, Edition de 1983.

Ohlin, B. G. (1933), Interregional and International Trade, Cambridge: Harvard University Press.

Paulré, B. (2004), "L’analyse évolutionniste contemporaine du changement technique et de l'innovation", Cahiers lillois d'Économie et Sociologie, Numéro spécial "L'économie industrielle en mutation", A. Hamdouch (éd.), n43-44, 1er et 2e semestres, pp. 191-241.

Posner, M. V. (1961), "International Trade and Technological Change," Oxford Economic Papers, vol. 13, n³, May, pp. 323-341.

Ricardo, A. (1817), On the Principles of Political Economy and Taxation, Ontario (Canada): Batoche Books, 2001.

Rogers, J., Sparviero, S. (2011), "Same Tune, Different Words: The Creative Destruction of the Music," Observatorio Journal Economy, vol. 5, n4, April, pp. 1-30.

Say, J.-B. (1803), Traité d'économie politique, Paris: Institut Coppet, Edition de 2011.

Schumpeter, J. A. (1912), La théorie de l'évolution économique, Paris: Dalloz, Édition de 1935.

Schumpeter, J. A. (1927), "The Explanation of the Business Cycle," Economica, December, vol. 21, pp. 286-311.

Schumpeter, J. A. (1935), "The Analysis of Economic Change," Review of Economic Statistics, vol. 17, May, pp. 2-10.

Schumpeter, J. A. (1937), "Preface to Japanese Edition of 'Theorie Der Wirtschaftlichen Entwicklung'", in Richard V. Clemence (ed.), Essays, Brunswick: Transaction Publisher, pp. 165-168.

Schumpeter, J. A. (1943a), "Capitalism in the Postwar World," in Seymour E. Harris (ed.), Postwar Economic Problems, New York and London: McGraw-Hill.

Schumpeter, J. A. (1943b), Capitalism, Socialism and Democracy, London: Routledge, edition of 2010.

Schumpeter, J. A. (1946), “Capitalism,” Encyclopedia Britannica, vol. IV, pp. 801-807.

Schumpeter, J. A. (1947), "The Creative Response in Economic History," Journal of Economic History, vol. 7, November, pp. 149-159. 
Schumpeter, J. A. (1991), The Economics and Sociology of Capitalism, Princeton: Princeton University Press.

Smith, A. (1776), An Inquiry into the Nature and Causes of the Wealth of Nations, An Electronic Classics Series Publication, 2005, University Park, PA: Pennsylvania State University Press.

Vernon, R. (1966), "International Investment and International Trade in the Product Cycle," The Quarterly Journal of Economic History, vol. 80, n², May, pp. 190-207. 